\title{
IMPLEMENTASI PERMENDIKBUD NO. 111 TAHUN 2014 DAN IMPLIKASINYA TERHADAP URAIAN TUGAS DAN KOMPETENSI GURU BIMBINGAN \& KONSELING
}

\author{
Riskiyah \\ SMA Negeri 2 Sumenep \\ E-mail: upbk.smadasumenep@yahoo.com
}

\begin{abstract}
Abstrak
Artikel ini berisi ulasan mengenai seperangkat tugas guru BK dalam implementasi program bimbingan dan konseling berdasarkan Permen Dikbud No 111 Tahun 2014, untuk melakukan tugas-tugas tersebut ada seperangkat kompetensi yang harus dimiliki oleh guru BK. Ulasan tugas dan syarat kompetensi berikut merupakan hasil dari pengkajian literatur tentang program bimbingan dan konseling komprehensif. Disajikan pula sistematika dalam mengimplementasikan keempat komponen program beserta konten dan strategi layanan yang telah digunakan selama dua tahun di SMA Negeri 2 Sumenep. Gagasan ini dapat menjadi alternatif model dalam mengembangkan program BK seperti yang diamanatkan dalam Permen Dikbud No 111 Tahun 2014.
\end{abstract}

Kata Kunci: Permendikbud No. 111 2014, Program BK komprehensif, kompetensi konselor.

\section{Abstract}

This article describes about a set of school counselor duty regard to implementation of school counseling program according to Permen Dikbud No 111 Tahun 2014, in order to conduct the duties there is a set of competencies which is every counselor should have. The following job description and competencies is yield of many literature review about comprehensive school counseling program. Additionally there is an example of how to implement the four component of counseling program with some content and techniques that have been applied since last two years ago in SMA Negeri 2 Sumenep, this concept can be an alternate model in order to develop school counseling program according to Permen Dikbud No 111 Tahun 2014.

Keywords: Permendikbud No. 111 Tahun 2014, comprehensive school counseling program, school counselor competencies.

\section{PENDAHULUAN}

Peraturan Pemerintah Nomor 84 Tahun 1993 Tentang Jabatan Fungsional Guru dan Angka Kreditnya Pasal 3 menegaskan bahwa "tugas pokok guru pembimbing adalah menyusun program bimbingan, melaksanakan program bimbingan, mengevaluasi pelaksanaan bimbingan, analisis hasil pelaksanaan bimbingan, dan tindak lanjut dalam program bimbingan terhadap peserta didik yang menjadi tanggung jawabnya".

Dalam Undang-Undang Republik Indonesia Nomor 14 tahun 2005 tentang guru dan dosen, dijelaskan bahwa: "Kompetensi adalah seperangkat pengetahuan, keterampilan, dan perilaku yang harus dimiliki, dihayati, dan dikuasai oleh guru atau dosen dalam melaksanakan tugas keprofesionalan." Selanjutnya dalam Permendiknas No. 27 tahun 2009 tentang Standar Kualifikasi Akademik dan Kompetensi Konselor dinyatakan bahwa kompetensi yang harus dikuasai guru Bimbingan dan Konseling/Konselor mencakup 4 (empat) ranah kompetensi, yaitu: kompetensi pedagogik, kompetensi kepribadian, kompetensi sosial, dan kompetensi profesional. Keempat rumusan kompetensi ini menjadi dasar bagi Penilaian Kinerja Guru Bimbingan dan Konseling/Konselor.

Profesi konselor/guru BK telah memperoleh pengakuan, peran serta fungsinya telah tegas tertulis, namun melihat tantangan yang ada dewasa ini para pendidik dituntut untuk bekerja keras. Sekarang bukan lagi waktunya untuk membahas tentang peran dan fungsi guru BK, tetapi harus lebih berfokus kepada bagaimana guru BK berkontribusi terhadap keberhasilan siswa, guru BK harus dapat membuktikan bahwa layanan bimbingan dan konseling memberikan dampak terhadap peserta didik.

Penelitian yang dilakukan oleh Badrujaman dkk yang bertujuan untuk mengetahui kontribusi pemberian layanan dasar terhadap pencapain hasil belajar siswa di SMP Negeri seluruh Jakarta timur, hasilnya adalah rerata kontribusi layanan dasar sebesar 4, 26\%, dan temuan yang juga memprihatinkan terdapat $26,07 \%$ layanan dasar tidak memiliki kontribusi terhadap pencapaian prestasi (Prosiding Kongres ABKIN XII, 2013). Tidak berkontribusinya layanan dasar terhadap hasil belajar dapat dikarenakan tidak dilakukannya penilaian terhadap hasil bimbingan, umumnya guru BK melakukan penilaian terhadap keterlaksanaan program saja, penilaian terhadap capaian kompetensi siswa sebagai hasil dari bimbingan jarang dilakukan. Sebagai bagian dari program pendidikan di sekolah semestinya layanan bimbingan dan konseling dapat memberikan kontribusi terhadap capaian prestasi siswa, seperti halnya guru mata pelajaran guru BK juga harus memenuhi tuntutan akuntabilitas.

Terbitnya Permendikbud No 111 Tahun 2014 mengamanatkan reorganisasi program BK, bila selama 
ini pemberian layanan di sekolah-sekolah hanyalah bimbingan klasikal (layanan dasar) dan penanganan terhadap siswa bermasalah (layanan responsif), serta lemahnya penilaian hasil layanan, maka tibalah saatnya program BK menjadi komprehensif dan akuntabel. Sebenarnya program BK komprehensif telah tercetus sejak akhir tahun 1960-an hingga awal 1970-an oleh seorang professor dari Universitas Missouri Columbia. Sebelumnya Norman C Gysbers melihat segi profesionalitas konselor sekolah, dan pada saat itu mulai memfokuskan terhadap tujuan strategis dan sistemik dari program konseling yang developmental dan komprehensif.

Program BK komprehensi berimplikasi terhadap deskripsi tugas guru BK, sehingga memerlukan beberapa kompetensi tertentu yang mungkin selama ini belum dimiliki. Walaupun deskripsi tugas dan standar kompetensi konselor/guru BK telah ada dalam undangundang tentang guru dan dosen, dan dalam peraturan pemerintah tetapi uraian tugas dan kompetensi yang diuraikan tersebut belum secara rinci mengacu kepada kompetensi untuk pelaksanaan komponen program. Namun sejumlah literatur tentang program BK komprehensif dan model-model program BK komprehensif yang telah dikembangkan oleh banyak negara-negara barat dapat dijadikan acuan untuk mengetahui tugas-tugas apa saja yang harus dilakukan guru BK dan kompetensi-kompetensi apa saja yang perlu digunakan untuk operasionalisasi Permendikbud No 111 Tahun 2014.

\section{PEMBAHASAN}

\section{Program Bimbingan dan Konseling Komprehensif}

Permendikbud No. 111 Tahun 2014 mengamanatkan program bimbingan dan konseling komprehensif harus dilakukan secara massif dan sistematis, karena telah sekian lama bimbingan dan konseling telah diakui sebagai bagian yang integral dalam pendidikan di sekolah, maka memang seharusnya layanan BK benar-benar memberikan dampak terhadap prestasi peserta didik.

Gysbers (2001) menjelaskan tiga karakteristik program BK komprehensif, yaitu program memiliki cakupan menyeluruh (comprehensive in Scope), dirancang secara preventif (Preventive in Design) dan bersifat developmental (developmental in nature). (1) Program memiliki cakupan luas, yaitu berfokus terhadap apa yang harus peserta didik ketahui, pahami dan dapat lakukan dalam empat bidang, pribadi, sosial, belajar dan karier. Program yang menitik beratkan kepada kesuksesan akademik seluruh siswa, program membantu seluruh siswa untuk mencapai kesuksesan di sekolah sehingga berkembang untuk berkontribusi sebagai anggota masyarakat; (2) Program dirancang secara preventif, yang bertujuan untuk menanamkan keterampilan-keterampilan khusus dan kesempatankesempatan belajar secara proaktif dan preventif untuk menjamin seluruh siswa dapat meningkatkan kesuksesan akademik, karier, pribadi dan sosial melalui layanan yang memberikan pengalaman-pengalaman untuk perkembangannya, seperti penyampaian kurikulum bimbingan secara klasikal atau berkoordinasi dengan program pendidikan di sekolah: (3) Program bersifat developmental, artinya guru BK merancang program dan layanan-layanan untuk memenuhi kebutuhan para siswa dalam berbagai tahap pertumbuhan dan perkembangan. Dalam program ditetapkan tujuan, harapan, dukungan system dan pengalaman-pengalaman bagi seluruh siswa.

Empat komponen program yang mencakup layanan dasar, perencanaan individual, layanan responsif dan dukungan system harus diimplementasikan. Layanan dasar yang disebut juga dengan kurikulum bimbingan karena layanan ini berdasarkan atas kurikulum bimbingan, kegiatannya adalah pokok dalam konteks jadwal reguler di sekolah, bimbingan ini dapat menjadi bagian dari tujuan instruksional atau diorganisasikan dalam topik-topik khusus yang dikemas dalam unit-unit, modul atau paket khusus. Topik bimbingan berdasarkan pada kebutuhan perkembangan peserta didik yang telah dirumuskan ke dalam tujuan dan kompetensi-kompetensi tertentu yang hendak dicapai oleh peserta didik serta aktifitas-aktifitas yang dirancang untuk mencapai tujuannya (Gysbers \& Henderson :2001).

Panduan pengembangan program BK Florida (2010), memberikan perbandingan antara sifat program BK komprehensif dengan non komprehensif.

Gambar 1. Perbandingan program BK komprehensif dengan non komprehensif berdasarkan sifatnya.

\begin{tabular}{|l|l|}
\hline \multicolumn{1}{|c|}{$\begin{array}{c}\text { Traditional } \\
\text { Guidance }\end{array}$} & \multicolumn{1}{c|}{$\begin{array}{c}\text { Comprehensive Student } \\
\text { Development }\end{array}$} \\
\hline Isolation & kolaborasi \\
\hline Reaktif & Proaktif \\
\hline krisis & Preventif dan krisis \\
\hline Penyesuaian & pengembangan \\
\hline Defisien & Kuat \\
\hline Terbatas & komprehensif \\
\hline Terlepas dari kurikulum & $\begin{array}{l}\text { Terintegrasi dengan } \\
\text { kurikulum }\end{array}$ \\
\hline Berorientasi proses & Berorientasi hasil \\
\hline Populasi khusus & Seluruh siswa \\
\hline Layanan informasi karier & $\begin{array}{l}\text { Perencanaan karier dan } \\
\text { pengembangan }\end{array}$ \\
\hline Kegiatan tidak terencana & Kegiatan harian terencana \\
\hline Staf BK & Seluruh personel sekolah \\
\hline Akuntabilitas lemah & Akuntabilitas tinggi \\
\hline
\end{tabular}

Florida Department of Education (2010) Florida's School Counseling Framework.

Para siswa dan orang tua memiliki hak untuk mengharapkan adanya kepekaan dan ketanggapan dari sekolah terhadap kebutuhan-kebutuhan unik setiap siswa dalam perkembangannya, seperti diantaranya adalah kebutuhan untuk menetapkan tujuan dan perencanaan karier, untuk itulah komponen perencanaan individual diperlukan (Gysber et al, 2011). Melalui layanan perencanaan individual disediakan informasi untuk setiap siswa dan mereka dibantu dalam menggunakan keterampilan-keterampilan yang dibutuhkan untuk 
membuat rencana-rencana serta mengambil langkah yang sesuai untuk pencapaian tujuannya itu (Gysbers, 2006). Tujuan dari komponen perencanaan individual dalam program BK komprehensif adalah menyediakan kegiatankegiatan untuk seluruh siswa dalam membantu mereka menilai, merencanakan dan kemudian memantau serta mengelolah pribadi sosial, akademik dan pengembangan karir. Kegiatan-kegiatan itu bertujuan agar siswa terfokus pada tujuan-tujuan jangka pendek dan tujuan masa depan mereka melalui pengembangan perencanaan diri dalam belajar yang telah tergambar dalam materi layanan dasar (kurikulum bimbingan).

Layanan responsif adalah komponen dimana beberapa siswa dibantu dalam mengatasi masalahmasalah yang tengah dihadapi, yang berhubungan dengan kesehatan pribadi, sosial, karir dan belajarnya. Tujuan dari layanan responsif adalah menangani sejumlah siswa yang tengah mengalami persoalan atau masalah yang dapat beresiko terhadap perkembangan pribadi, sosial, akademik dan kariernya, serta untuk merespon kebutuhan siswa, orang tua dan guru akan informasi-informasi tertentu (Gysbers, 2006). Untuk melaksanakan komponen ini diperlukan penggunaan perencanaan dan kebijakankebijakan secara tegas mengenai kerahasiaan, agar konselor dapat merespon terhadap permintaan informasi dengan tepat dan membantu konselor dalam bekerja dengan para siswa, para orang tua, guru dan kepala sekolah (Gysbers, 2011).

Komponen dukungan sistem merupakan layananlayanan dan kegiatan-kegiatan pengelolaan yang secara tidak langsung menunjang terhadap para siswa. Komponen bertujuan untuk mendukung pemenuhan kebutuhan-kebutuhan dalam sistem pendidikan dalam menjamin efektifitas pelaksanaan dari ketiga komponen serta untuk memfasilitasi pelaksanaan dari keseluruhan program dalam sistem pendidikan. Administrasi dan pengelolaan program BK memerlukan dukungan yang berkelanjutan sehingga dukungan sistem merupakan komponen penting, tanpa adanya dukungan berkelanjutan ketiga komponen yang lain tidak akan dapat efektif.

Layanan dasar dilakukan untuk memberikan pengetahuan dasar bagi setiap siswa dalam mengembangkan aspek pribadi, sosial, belajar dan karier. Selanjutnya setiap siswa akan melakukan perencanaan dalam mengembangkan pribadi, keterampilan sosial, belajar dan karier melalui komponen perencanaan individual siswa diajarkan cara dalam menilai, membuat rencana, memonitor serta mengelolah pribadi sosial, belajar dan perencanaan karirnya. Masalah yang ditemui dalam proses pengembangan ditangani melalui layanan responsif. Dalam pemberian ketiga layanan tersebut membutuhkan dukungan ketersediaan dan pengelolaan sumber-sumber daya yang meliputi: tenaga, materi bimbingan, media, sarana prasarana dan administrasi. Seluruh kegiatan untuk pemenuhan faktor pendukung itu merupakan dukungan system. Seluruh komponen program dirancang untuk pencapaian visi dan misi bimbingan dan konseling yang selaras dengan visi dan misi sekolah.

Kaitan antara kurikulum bimbingan dengan perencanaan individual secara jelas tergambar dalam lima elemen dalam Washington's Navigation 101 program (Washington State Office of Superintendent of Public Instruction, 2007). Elemen itu meliputi:

1. Personalisasi (personalizing), materi kurikulum bimbingan merupakan elemen pertama, kurikulum memberikan siswa tentang dasar dalam melakukan perencanaan;

2. Perencanaan (planning), pengembangan dan penggunaan portofolio;

3. Pelaksanaan (demonstrating), siswa melakukan konferensi dengan orang tua, guru dan konselor, untuk memberikan kesempatan siswa menggunakan kemampuan dalam perencanaan;

4. Menguasakan (empowering), menguasakan siswa untuk memilih alternatif kegiatan dalam pencapaian tujuannya;

5. Evaluasi (evaluation), membantu siswa dalam memahami dan menilai apa yang telah mereka capai.

\section{Uraian Tugas Guru Bimbingan \& Konseling}

Panduan-panduan pelaksanaan bimbingan dan konseling sejak kurikulum 1975 hingga pola 17 telah memberikan uraian tentang tugas guru BK, walaupun kenyataannya di sekolah tugas-tugas tersebut belum terlaksana dengan semestinya. Banyak guru BK belum memahami dengan baik tentang beberapa aktifitas yang harus dilakukan dalam program $\mathrm{BK}$ Pola 17 yang menguraikan tentang 17 aktifitas layanan dan kegiatan pendukung.

Mengutip dari Gysbers \& Henderson (1981) "Struktur baru dalam bimbingan di sekolah telah dibutuhkan, formula tradisional bimbingan yang mencakup sembilan layanan (orientasi, informasi, asesmen, konseling, penempatan dan follow-up) dan tiga aspek bimbingan (belajar, pribadi sosial dan karir) walaupun mungkin cukup akan tetapi tidak lagi menjadi cara yang memadai dalam mengorganisasikan program bimbingan di sekolah saat ini”. Bila dibandingkan dengan pola 17/17+ program BK komprehensif lebih memberikan kejelasan tentang apa saja fungsi dari program BK dan bagaimana fungsi-fungsi itu dijalankan. Program BK diklasifikasikan ke dalam 4 komponen yang masing-masing memiliki spesifikasi tujuan yang berbeda tetapi saling berkaitan dan saling mendukung satu sama lain.

Program BK komprehensif didasarkan pada kerangka kerja utuh konselor, artinya seorang konselor/guru BK idealnya harus melakukan tugas-tugas yaitu: (1) Melakukan asesmen, program dirancang berdasarkan data hasil asesmen lingkungan dan perkembangan konseli, asesmen lingkungan dilakukan untuk mengetahui tentang harapan-harapan orang tua, sekolah serta masyarakat terhadap peserta didik, dan untuk mengetahui kondisi lingkungan peserta didik. Asesmen terhadap perkembangan konseli menghasilkan tentang harapan-harapan dan kondisi konseli; (2) mengembangkan program, pada tahap pengembangan program yang dilakukan adalah: (a) Analisis hasil asesmen; (b) merumuskan kompetensi-kompetensi 
tertentu yang diharapkan untuk dicapai oleh peserta didik; (c) memilih atau mengklasifikasi kompetensikompetensi ke dalam domain pengembangan, pengembangan pribadi sosial, pengembangan belajar atau pengembangan karir; (3) melaksanakan program, program bimbingan dan konseling dilaksanakan dalam setiap komponennya melalui pendekatan (klasikal, kelompok dan individual) dan strategi-strategi layanan tertentu (Dirjen PMPTK, 2007).

Perbandingan tugas guru bk selama ini dengan tugas dalam program BK komprehensif.

Gambar.3 Perbandingan tugas guru bk dalam program BK komprehensif dan diluar program BK komprehensif

\begin{tabular}{|l|l|}
\hline \multicolumn{1}{|c|}{$\begin{array}{c}\text { Tugas-tugas di luar } \\
\text { program BK } \\
\text { komprehensif }\end{array}$} & \multicolumn{1}{c|}{$\begin{array}{c}\text { Tugas-tugas dalam } \\
\text { program BK } \\
\text { komprehensif }\end{array}$} \\
\hline $\begin{array}{l}\text { Mengurus pendaftaran } \\
\text { dan penjadwalan siswa } \\
\text { baru }\end{array}$ & $\begin{array}{l}\text { Meningkatkan prestasi } \\
\text { siswa melalui program } \\
\text { perencanaan belajar, } \\
\text { karier dan pribadi } \\
\text { sosial personal/social } \\
\text { program planning. }\end{array}$ \\
\hline $\begin{array}{l}\text { Bertanggungjawab } \\
\text { dalam pemberian izin } \\
\text { untuk siswa yang tidak } \\
\text { masuk }\end{array}$ & $\begin{array}{l}\text { Mengkonseling siswa } \\
\text { yang sering tidak } \\
\text { masuk }\end{array}$ \\
\hline $\begin{array}{l}\text { Melakukan tindakan } \\
\text { pemberian sanksi }\end{array}$ & $\begin{array}{l}\text { Mengkonseling siswa } \\
\text { yang melanggar tata } \\
\text { tertib }\end{array}$ \\
\hline $\begin{array}{l}\text { Mengurus kelengkapan } \\
\text { data siswa. }\end{array}$ & $\begin{array}{l}\text { Menginterpretasi data- } \\
\text { data siswa. }\end{array}$ \\
\hline $\begin{array}{l}\text { Memberi sanksi kepada } \\
\text { siswa yang bertengkar }\end{array}$ & $\begin{array}{l}\text { Memberikan guru saran } \\
\text { dalam menyelesaian } \\
\text { konflik dan masalah } \\
\text { dalam pengelolaan } \\
\text { kelas. }\end{array}$ \\
\hline
\end{tabular}

State of Arizona Department of Education. 2007.

The Arizona Model:A Framework for School

Counseling Programs.

Dalam model program BK komprehensif Texas (2004) menguraikan tugas-tugas konselor berdasarkan aktifitas-aktifitas dalam setiap komponen program, yaitu:

1. Uraian tugas konselor dalam kurikulum bimbingan meliputi:

a. Menyusun, melaksanakan dan merevisi rencana bimbingan yang mencakup bidang pengembangan pribadi sosial, belajar dan karier.

b. Menyampaikan kurikulum bimbingan kepada seluruh siswa secara sistematik.

c. Melakukan kolaborasi dengan sejawat di sekolah dan berbagai sumber di masyarakat dalam memfasilitasi proses bimbingan.

2. Uraian tugas guru BK dalam perencanaan individual meliputi:

a. Memberikan bimbingan dalam pengembangan, pelaksanaan dan evaluasi perencanaan siswa, yang hasilnya berupa rencana tertulis tentang perencananaan belajar dan karier untuk setiap siswa yang direvisi dan diperbaharui secara periodik.

b. Mengembangkan tujuan perencanaan individual secara tertulis dalam setiap jenjang kelas dan melaksanakan bimbingan.

c. Membantu peserta didik dalam memasuki studi lanjut.

d. Memberikan informasi kepada peserta didik dan orang tua tentang hasil asesmen dan implikasinya untuk perencanaan belajar dan karier.

3. Uraian tugas guru BK dalam layanan responsif meliputi:

a. Melakukan layanan yang berorientasi kepada tujuan konseling dan terhadap pemenuhan kebutuhan-kebutuhan.

b. Melakukan alih tangan kepada ahli dan lembaga lain.

c. Melakukan konseling individual dan kelompok dalam masalah pribadi sosial, belajar dan karier.

d. Melakukan penanganan atau memberi dukungan dalam situasi-situasi krisis..

e. Membantu para orang tua menghadapi masalah yang berhubungan dengan masalah siswa atau masalah siswa di sekolah.

f. Memberikan informasi kepada guru, orang tua untuk membantu perkembangan peserta didik.

g. Mentaati kode etik bimbingan dan konseling.

4. Uraian tugas guru BK dalam dukungan system adalah:

a. Berkonsultasi dengan teman sejawat, guru dan orang tua mengenai peserta didik.

b. Menjelaskan tentang tugas-tugas konselor/guru BK kepada sekolah dan masyarakat.

c. Mendukung perluasan akses terhadap program dan layanan untuk seluruh peserta didik.

d. Merencanakan dan mengkoordinasikan program yang lebih luas seperti college fair, bantuan keuangan dll.

e. Mengkaji ulang program setiap tahun.

f. Melakukan pengembangan profesionalisme.

g. Berkoordinasi dengan para orang tua dalam persiapan studi lanjut dan perencanaan belajar.

h. Menyusun kalender kegiatan.

i. Berpartisipasi dalam pengambilan keputusan sekolah.

j. Menunjukkan pengetahuan tentang kebijakankebijakan dan dasar hukum mengenai bimbingan dan konseling.

k. Menggunakan teknologi untuk peningkatan program.

Selanjutnya Asosiasi Konselor Sekolah Amerika (ASCA, 2005) menguraikan tentang tugas-tugas konselor yang lebih luas lagi, yaitu meliputi aktifitas layanan secara langsung dan tidak langsung, yang meliputi: 
a. Layanan langsung

1) Dalam layanan dasar: konselor melaksanakan kurikulum bimbingan; mengidentifikasi kurikulum yang sesuai dengan standar nasional kompetensi siswa; mengembangkan dan menampilkan kurikulum pokok berdasarkan data kebutuhan seluruh siswa; melakukan pengelolaan kelas dan keterampilan mengajar; mengembangkan materi dan strategi pengajaran dalam memenuhi kebutuhan siswa dan visi misi sekolah; mendorong keterlibatan staf untuk efektifitas pelaksanaan kurikulum bimbingan; mengetahui, memahami dan menggunakan berbagai teknologi dalam pelaksanaan kurikulum bimbingan; memahami keberagaman budaya dan kecendrungan pluralistic dalam mengembangkan dan memilih kurikulum pokok; memahami dan dapat membangun program peer helper yang efektif dan berkualitas tinggi.

2) Dalam perencanaan individual: memfasilitasi perencanaan individual; memahami bahwa perencanaan individual sebagai komponen dalam program yang komprehensif; mengembangkan strategi untuk melaksanakan perencanaan individual, seperti strategi dalam pemahaman diri siswa, pemberian saran, penetapan tujuan, keterampilan sosial, perencanaan studi lanjut; membantu siswa menetapkan tujuan dan mengembangkan serta menggunakan keterampilan dalam menyusun rencana melalui kolaborasi dengan orang tua/wali dan personel sekolah; memahami peluangpeluang karier, tren pasar kerja, ekonomi global dan menggunakan berbagai teknik asesmen untuk membantu siswa dalam memahami potensi dan minat karier mereka; membantu siswa belajar pentingnya pendidikan dan membantu siswa dalam proses memasuki studi lanjut; memahami hubungan antara kinerja akademik dan dunia kerja, keluarga dan layanan masyarakat; memahami metode dalam membantu siswa untuk memonitor dan mengarahkan belajar dan mengembangkan pribadi sosial dan karier.

3) Layanan responsif: melakukan layanan responsive; membuat daftar dan menjelaskan intervensi yang digunakan dalam layanan responsive seperti konseling perorangan atau kelompok dan penanganan krisis; memahami teori-teori tentang konseling perorangan atau kelompok dan teknik-teknik seperti dalam konseling rasional emotif, konseling realitas, konseling kognitif behavioral, Adlerian, konseling singkat berbasis solusi dan konseling keluarga; menunjukkan kemampuan dalam melakukan konseling.

b. Layanan tidak langsung

1) Konseling: menciptakan hubungan kepercayaan dan kerahasiaan dengan siswa baik perorangan maupun kelompok dalam membantu siswa menetapkan tujuan dan atau membuat perubahan perilaku; menekankan kepada problem solving, pengambilan keputusan, pengembangan pribadi sosial dan memperhatikan pengaruh belajar dan perkembangan; menggunakan teori-teori konseling dan teknik-teknik untuk membantu setiap siswa dalam meningkatkan keberhasilan dalam belajar, karier dan pribadi sosial; menganalisis dan mengeksplorasi perilaku dan sikap yang berpengaruh pada kemampuan siswa dalam belajar.

2) Koordinasi layanan: menentukan tujuan program konseling dan mengidentifikasi mekanisme dan sumber daya yang dibutuhkan dalam pencapaian tujuan; memprioritaskan, mengorganisasikan dan melaksanakan komponen-komponen program.

3) kepemimpinan: melayani sebagai pimpinan untuk yang terlibat dalam upaya perubahan yang luas untuk menjamin kesuksesan setiap siswa; membantu setiap siswa mencapai kesuksesan dalam persiapan belajar yang cermat yang akan mendukung terhadap kesempatan lebih/luas serta peningkatan prestasi akademik; mendukung kesuksesan siswa melalui penyediaan informasi, kesempatan dan mengatasi kesenjangan apapun yang mereka temui; berkolaborasi dengan professional lain di sekolah untuk memberi pengaruh terhadap system perubahan yang luas dan melakukan reformasi sekolah

4) Advokasi: menjamin kebutuhan akademik, pribadi sosial dan karier siswa; bekerja dengan proaktif dengan setiap siswa untuk menghilangkan hambatan dalam belajar; menyadari perbedaan dan membela terhadap penerimaan dan toleransi dalam latar ras dan etnis, status ekonomi, kemampuan dan pilihan gaya hidup.

5) Kolaborasi dan tim: mendorong kerjasama secara sungguh-sungguh diantara seluruh staf dalam bekerja demi keadilan, pemberian akses dan keberhasilan akademik bagi setiap siswa; bekerja dengan para stakeholder dalam mendukung prestasi setiap siswa; membangun rasa kebersamaan di sekolah melalui pemahaman dan apresiasi terhadap pemberi kontribusi dalam pendidikan anak. 
6) Pengelolaan sumber daya: menggunakan kreatifitas dalam menemukan dukungan internal dan eksternal serta melibatkan seluruh stakeholder dalam pelaksanaan program BK; menggunakan waktu dan sumber daya secara efisien untuk melayani setiap siswa.

7) Penginformasian data: menganalisis dan menginterpretasi data untuk mengidentifikasi dan merespon kebutuhan siswa; menggunakan data dalam bekerja untuk menemukan solusi masalah; memantau siswa dan menemukan strategi dalam meningkatkan prestasi siswa; menunjukkan bagaimana program BK memberikan dampak positif terhadap prestasi siswa dan pengembangan sekolah melalui pengkoordinasian sumber-sumber daya.

8) Penggunaan teknologi: menggunakan teknologi dengan cara efisien dan efektif dalam mendiseminasikan informasi dan hasil-hasil analisis; menggunakan keterampilan dasar computer, pengetahuan tentang sumber-sumber internet dan perangkat lunak yang berhubungan dengan BK; memanfaatkan kantor BK untuk membantu siswa mengakses internet untuk bimbingan karier, proses perencanaan studi lanjut, dan sumber-sumber yang dapat mendukung program $\mathrm{BK}$; mengambil tindakan-tindakan yang sesuai dan beralasan dalam menjaga kerahasiaan informasi tentang siswa; berkolaborasi dengan sekolah untuk mengajarkan siswa tentang keamanan dalam menggunakan internet.

\section{Kompetensi Guru Bimbingan dan Konseling}

Untuk melakukan seperangkat tugas dalam melaksanakan program BK komprehensif guru BK memerlukan kompetensi-kompetensi tertentu. Walaupun standar kompetensi konselor/guru BK telah ada dalam undang-undang tentang guru dan dosen, tetapi kompetensi-kompetensi yang diuraikan tersebut belum secara rinci mengacu kepada kompetensi dalam pelaksanaan komponen program. Namun sejumlah literature tentang program BK komprehensif dan modelmodel program BK komprehensif yang telah dikembangkan oleh banyak negara-negara barat dapat dijadikan acuan untuk mengetahui kompetensikompetensi apa saja yang harus digunakan untuk bekerja dalam setiap komponen program.

Dalam pedoman penyusunan program BK Springfield Public Schools, New York, Johnson et al (2009), membandingkan kompetensi yang digunakan antara program BK komprehensif dengan program nonkomprehensif.
Gambar 4. Perbandingan Kompetensi Guru BK dalam Program BK Komprehensif dan Program Non-Komprehensif.

\begin{tabular}{|c|c|}
\hline $\begin{array}{l}\text { Program Non- } \\
\text { Komprehensif }\end{array}$ & Program Komprehensif \\
\hline $\begin{array}{l}\text { - Konseling } \\
\text { - Konsultasi } \\
\text { - Koordinasi }\end{array}$ & $\begin{array}{l}\text { - Konseling } \\
\text { - Koordinasi layanan- } \\
\text { layanan } \\
\text { - Konsultasi } \\
\text { - Kepemimpinan } \\
\text { - Advokasi keadilan } \\
\text { sosial } \\
\text { - Angen perubahan } \\
\text { sistematis } \\
\text { - Kolaborasi dan } \\
\text { Teaming } \\
\text { - Pengelolaan sumber } \\
\text { daya } \\
\text { - Penginformasian data } \\
\text { - Penggunaan teknologi } \\
\quad \text { Model berdasarkan } \\
\quad \text { data dan standar }\end{array}$ \\
\hline
\end{tabular}

Education Trust 1997, dalam Springfield Public Schools (2009). Comprehensive School Counseling Program Guide.

Dalam Connecticut School Counselor Association (2001) dijelaskan bahwa konselor professional dalam melaksanakan komponen program yang komprehensif harus memiliki kompetensikompetensi tertentu.

1. Pemberian layanan dasar berhubungan dengan kompetensi konselor dalam beberapa hal, yaitu:

a. Dapat merancang dan menyusun rencana bimbingan yang sesuai untuk perkembangan peserta didik.

b. Dapat mengimplementasikan rencana bimbingan yang telah disusun, guru BK harus memiliki keterampilan mengajar, menyampaikan materi bimbingan dengan baik dan sistematik kepada siswa.

c. Memiliki pemahaman tentang teori-teori dan strategi pembelajaran agar dapat merancang bimbingan klasikal yang bermakna dan lebih bervariatif.

d. Dapat melakukan evaluasi terhadap hasil dari bimbingan dan memodifikasi metode-metode bimbingan berdasarkan feedback yang diperoleh.

2. Dalam layanan perencanaan individual konselor harus memiliki beberapa kompetensi minimal yaitu:

a. Memiliki keterampilan dalam penggunaan asesmen non tes untuk membantu siswa dalam memahami diri tentang kekuatan-kekuatan, kekurangan, bakat dan minatnya.

b. Pengetahuan dan keterampilan dalam pemberian informasi tentang hasil asesmen serta bagaimana siswa menggunakan informasi itu untuk 
mengembangkan pribadi, keterampilan sosial, keterampilan belajar serta karirnya;

c. Menunjukkan kemampuan dalam membantu peserta didik dalam menetapkan tujuan-tujuan dan perencanaan masa depan.

d. Mengetahui metode dalam memberian layanan perencanaan individual secara sistematik untuk peserta didik sesuai dengan usia dan jenjang pendidikannya.

e. Dapat menunjukkan kemampuan dalam menginterpretasi tes, data siswa dan hasil pemahaman individu yang lain.

f. Menunjukkan pengetahuan mengenai berbagai instrument dan teknik untuk membantu peserta didik dalam membuat keputusan dan melakukan perencanaan.

3. Kompetensi guru BK dalam layanan responsif adalah:

a. Menunjukkan pengetahuan terhadap teori, praktik dan keterampilan dalam konseling individual dan kelompok.

b. Mengetahui dasar teori dalam praktik konseling.

c. Menunjukkan reknik-teknik dan cara-cara bantuan dalam bidang pribadi, sosial belajar dan karier.

d. Menunjukkan mengetahuan mengenai proses alih tangan kasus.

e. Menunjukkan cara-cara dalam mengadvokasi siswa dan mengajarkan siswa untuk mengadvokasi dirinya.

f. Menilai efektifitas dari bantuan dan melakukan tindak lanjut berdasarkan hasil dari penilaian.

g. Menunjukkan pengetahuan terhadap kode etik bimbingan dan konseling.

4. Kompotensi dan uraian tugas guru BK dalam dukungan sistem

a. Menunjukkan pengetahuan mengenai sumbersumber daya di sekolah dan masyarakat.

b. Bekerja sama dengan sejawat dan masyarakat.

c. Berinisiatif dan memelihara hubungan yang produktif dengan peserta didik, sejawat, para orang tua dan lembaga-lembaga di masyarakat.

d. Mengelolah waktu, tenaga dan materi dalam program BK.

e. Menunjukkan pengetahuan tentang riset dan metode evaluasi program.

f. Memanfaatkan teknologi.

g. Menunjukkan pengetahuan dalam melakakukan konsultasi.

h. Menunjukkan pengetahuan tentang standar nasional dan kebijakan-kebijakan mengenai bimbingan dan konseling.

Dalam panduan penyusunan program BK Prekindergarten Sout Carolina (2008) menguraikan tentang kompetensi-kompetensi yang dibutuhkan oleh konselor dalam menjalankan komponen-komponen program BK komprehensif.
Gambar 5. Kompetensi-kompetensi yang dibutuhkan dalam implementasi program BK komprehensif

\begin{tabular}{|c|c|}
\hline Peran Konselor & Program Komponen \\
\hline $\begin{array}{l}\text { 1. Menejemen program } \\
\text { - Merencanakan, } \\
\text { melaksanakan dan } \\
\text { mengevaluasi program } \\
\text { BK komprehensif } \\
\text { termasuk layanan } \\
\text { konseling. } \\
\text { - Mensupervisi kegiatan } \\
\text { yang dilakukan } \\
\text { personel administrasi. }\end{array}$ & - Dukungan system \\
\hline $\begin{array}{l}\text { 2. Bimbingan } \\
\text { - Mengkoordinasikan } \\
\text { kurikulum bimbingan. } \\
\text { - Membantu guru dalam } \\
\text { mengajarkan topic } \\
\text { bimbingan. } \\
\text { - Membimbing siswa } \\
\text { secara individu atau } \\
\text { kelompok untuk } \\
\text { pengembangan } \\
\text { belajar, pribadi sosial } \\
\text { dan perencanaan } \\
\text { pribadi. }\end{array}$ & $\begin{array}{l}\text { - Kurikulum } \\
\text { bimbingan } \\
\text { - Kurikulum } \\
\text { bimbingan }\end{array}$ \\
\hline $\begin{array}{l}\text { 3. Konseling } \\
\text { - Melakukan konseling } \\
\text { perorangan sesuai } \\
\text { dengan kebutuhan atau } \\
\text { masalah siswa. } \\
\text { - Melakukan konseling } \\
\text { kelompok sesuai } \\
\text { dengan kebutuhan atau } \\
\text { masalah siswa. } \\
\text { - Menggunakan teori- } \\
\text { teori dan teknik-teknik } \\
\text { yang sesuai untuk } \\
\text { konseling di sekolah. }\end{array}$ & $\begin{array}{l}\text { - Layanan responsif } \\
\text { - Layanan responsif }\end{array}$ \\
\hline $\begin{array}{l}\text { 4. Konsultasi dan } \\
\text { advokasi siswa } \\
\text { - Berkonsultasi dengan } \\
\text { orang tua, guru, } \\
\text { kepala sekolah dan } \\
\text { pihak lain yang } \\
\text { relevan untuk } \\
\text { meningkatkan } \\
\text { pembinaan siswa. }\end{array}$ & $\begin{array}{ll}\text { - } & \text { Layanan } \\
\text { responsif } \\
\text { - } & \text { Perencanaan } \\
\text { individual }\end{array}$ \\
\hline $\begin{array}{l}\text { 5. Koordinasi } \\
\text { - Berkoordinasi dengan } \\
\text { personel sekolah dan } \\
\text { masyarakat untuk } \\
\text { memperoleh sumber- } \\
\text { sumber yang } \\
\text { dibutuhkan siswa. }\end{array}$ & - Layanan responsif \\
\hline $\begin{array}{l}\text { - Menggunakan proses } \\
\text { referral dalam } \\
\text { membantu siswa dan }\end{array}$ & - Layanan responsif \\
\hline
\end{tabular}




\begin{tabular}{|l|l|}
\hline \multicolumn{1}{|c|}{ Peran Konselor } & Program Komponen \\
\hline $\begin{array}{l}\text { pihak lain untuk } \\
\text { memperoleh bantuan } \\
\text { atau layanan khusus } \\
\text { yang dibutuhkan. }\end{array}$ & \\
\hline 6. Asesmen & \\
- Ikut serta dalam & • Dukungan system \\
perencanaan dan & • Perencanaan \\
evaluasi program & individual \\
dalam & - Layanan responsif \\
tes sekolah & \\
- Menginterpretasi tes \\
dan hasil pemahaman \\
individu lain yang \\
sesuai. \\
- Menggunakan \\
sumber data siswa \\
lain yang sesuai \\
untuk kebutuhan \\
asesmen \\
South Carolina Department of Education. 2008. South \\
Carolina Comprehensive School Counseling Program \\
Guide.
\end{tabular}

\section{MODEL PROGRAM BIMBINGAN KONSELING KOMPREHENSIF}

Setiap komponen dalam program BK komprehensif terintegrasi satu sama lain sehingga tidak dapat terpisahkan, dan dalam eksekusinya menggunakan tata urutan logis, seperti digambarkan dalam gambar 6 .

Gambar 6. Urutan Logis Implementasi Komponen Program Bimbingan dan Konseling.

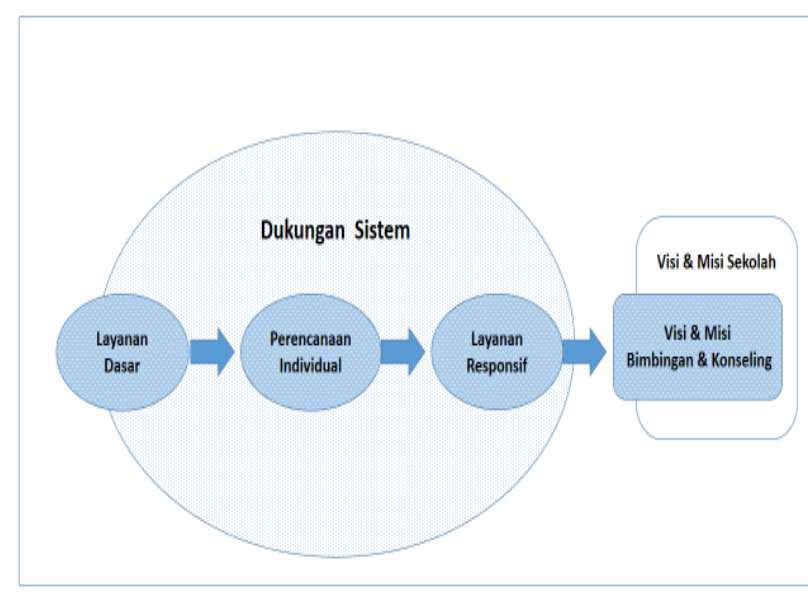

Program BK komprehensif dikembangkan berdasarkan data kebutuhan, sehingga setiap sekolah dapat memiliki keunikan satu sama lain, walaupun konten dalam kurikulum bimbingan harus disesuaikan dengan standar kompetensi/tugas perkembangan peserta didik. Berikut disajikan contoh konten beserta strategi layanan dalam setiap komponen dalam program tahunan.

\section{Program Bimbingan \& Konseling SMA Negeri 2 Sumenep \\ Tahun 2015-2016}

I. Layanan Dasar

\begin{tabular}{|c|c|c|}
\hline Konten & Strategi & $\begin{array}{c}\text { Dukungan } \\
\text { sistem }\end{array}$ \\
\hline $\begin{array}{l}\text { Mengembangkan } \\
\text { konsep diri } \\
\text { positif }\end{array}$ & $\begin{array}{l}\text { Ceramah, } \\
\text { menonton } \\
\text { film, diskusi } \\
\text { (klasikal) }\end{array}$ & \multirow{3}{*}{$\begin{array}{l}\text { Konsultasi, } \\
\text { kolaborasi } \\
\text { dan } \\
\text { koordinasi dg } \\
\text { kepala } \\
\text { sekolah, guru } \\
\text { dan orang tua } \\
\text { dlm } \\
\text { perancangan } \\
\text { program }\end{array}$} \\
\hline $\begin{array}{l}\text { Perilaku } \\
\text { bertanggung } \\
\text { jawab }\end{array}$ & $\begin{array}{l}\text { Ceramah, } \\
\text { diskusi } \\
\text { (klasikal) } \\
\end{array}$ & \\
\hline $\begin{array}{l}\text { Remaja yang } \\
\text { sukses dalam } \\
\text { pergaulan }\end{array}$ & $\begin{array}{l}\text { Menonton } \\
\text { film, } \\
\text { ceramah } \\
\text { (klasikal) }\end{array}$ & \\
\hline $\begin{array}{l}\text { Gaya belajar \& } \\
\text { strategi belajar } \\
\text { efektif efisien }\end{array}$ & $\begin{array}{l}\text { Penggunaan } \\
\text { inventori } \\
\text { gaya belajar; } \\
\text { ceramah } \\
\text { (klasikal) }\end{array}$ & $\begin{array}{l}\text { Penyusunan } \\
\text { materi } \\
\text { Penyiapan } \\
\text { media }\end{array}$ \\
\hline $\begin{array}{l}\text { Pengenalan } \\
\text { tentang } \\
\text { kecerdasan }\end{array}$ & $\begin{array}{l}\text { Penggunaan } \\
\text { inventori } \\
\text { kecerdasan } \\
\text { majemuk; } \\
\text { ceramah }\end{array}$ & $\begin{array}{l}\text { Penyusunan } \\
\text { instrument } \\
\text { penilaian } \\
\text { Proses }\end{array}$ \\
\hline $\begin{array}{l}\text { Nilai-nilai } \\
\text { kehidupan dan } \\
\text { pemilihan karier }\end{array}$ & $\begin{array}{l}\text { Menonton } \\
\text { film; diskusi } \\
\text { (klasikal) }\end{array}$ & $\begin{array}{l}\text { penilaian } \\
\text { Perencanaan } \\
\text { tindak lanjut }\end{array}$ \\
\hline Kewirausahaan & $\begin{array}{l}\text { Ceramah } \\
\text { (klasikal); } \\
\text { karya wisata }\end{array}$ & \\
\hline $\begin{array}{l}\text { Remaja anti } \\
\text { korupsi }\end{array}$ & $\begin{array}{l}\text { Menonton } \\
\text { film; diskusi } \\
\text { (klasikal) }\end{array}$ & laporan \\
\hline $\begin{array}{l}\text { Persiapan Ujian } \\
\text { Nasional }\end{array}$ & $\begin{array}{l}\text { Ceramah } \\
\text { (klasikal) }\end{array}$ & \\
\hline
\end{tabular}

II. Perencanaan Individual

\begin{tabular}{|l|l|l|}
\hline \multicolumn{1}{|c|}{ Konten } & \multicolumn{1}{|c|}{ Strategi } & \multicolumn{1}{c|}{$\begin{array}{c}\text { Dukungan } \\
\text { sistem }\end{array}$} \\
\hline $\begin{array}{l}\text { Pemahaman } \\
\text { hasil } \\
\text { asesmen } \\
\text { psikologis }\end{array}$ & $\begin{array}{l}\text { Pemberian } \\
\text { informasi, } \\
\text { interpretasi hasil } \\
\text { tes } \\
\text { (kelompok/perora } \\
\text { ngan) }\end{array}$ & $\begin{array}{l}\text { Penyusunan } \\
\text { materi }\end{array}$ \\
\cline { 1 - 1 } $\begin{array}{l}\text { Perencanaan } \\
\text { belajar }\end{array}$ & $\begin{array}{l}\text { Penetapan tujuan } \\
\text { belajar } \\
\text { kelompok/perora } \\
\text { ngan) }\end{array}$ & $\begin{array}{l}\text { Penyiapan } \\
\text { media }\end{array}$ \\
\hline
\end{tabular}




\begin{tabular}{|c|c|c|}
\hline Konten & Strategi & $\begin{array}{c}\text { Dukungan } \\
\text { sistem }\end{array}$ \\
\hline $\begin{array}{l}\text { Perencanaan } \\
\text { karier \& } \\
\text { studi lanjut }\end{array}$ & $\begin{array}{l}\text { Pemberian } \\
\text { informasi tentang } \\
\text { perguruan tinggi } \\
\text { \& bidang karier } \\
\text { (kelompok/perora } \\
\text { ngan); } \\
\text { Penetapan tujuan } \\
\text { karier \& studi } \\
\text { lanjut Konferensi } \\
\text { bersama orang tua } \\
\text { dan siswa }\end{array}$ & $\begin{array}{l}\text { Penyusunan } \\
\text { instrument } \\
\text { penilaian } \\
\text { Pelatihan guru } \\
\text { BK pemula } \\
\text { Proses penilaian } \\
\text { Perencanaan } \\
\text { tindak lanjut } \\
\text { Penvusunan }\end{array}$ \\
\hline $\begin{array}{l}\text { Pemantauan } \\
\text { hasil belajar }\end{array}$ & $\begin{array}{l}\text { Menilai hasil } \\
\text { pencapaian target } \\
\text { dan rencana } \\
\text { tindak lanjut; } \\
\text { Pemantauan } \\
\text { persiapan rencana } \\
\text { studi lanjut } \\
\text { (kelompok/perora } \\
\text { ngan); } \\
\text { Menilai hasil } \\
\text { pencapaian target } \\
\text { dan Perencanaan } \\
\text { tindak lanjut } \\
\text { (kelompok/perora } \\
\text { ngan) }\end{array}$ & laporan \\
\hline
\end{tabular}

III. Layanan Responsif

\begin{tabular}{|c|c|c|}
\hline Konten & Strategi & $\begin{array}{c}\text { Dukungan } \\
\text { sistem }\end{array}$ \\
\hline $\begin{array}{l}\text { Penanganan } \\
\text { siswa yang } \\
\text { tidak } \\
\text { mencapai } \\
\text { KKM }\end{array}$ & $\begin{array}{l}\text { Konferensi } \\
\text { bersama orang } \\
\text { tua, wali kelas dan } \\
\text { guru mapel }\end{array}$ & \multirow{2}{*}{$\begin{array}{l}\text { Konsultasi, } \\
\text { kolaborasi dan } \\
\text { koordinasi dg } \\
\text { kepala sekolah, } \\
\text { guru dan orang } \\
\text { tua dlm } \\
\text { perancangan } \\
\text { program }\end{array}$} \\
\hline $\begin{array}{l}\text { Mengatasi } \\
\text { stress }\end{array}$ & $\begin{array}{l}\text { Konseling kognitif } \\
\text { behavioral } \\
\text { (kelompok/ } \\
\text { perorangan) }\end{array}$ & \\
\hline $\begin{array}{l}\text { Mengatasi } \\
\text { kejenuhan } \\
\text { belajar }\end{array}$ & $\begin{array}{l}\text { Bimbingan } \\
\text { kelompok }\end{array}$ & \multirow{4}{*}{$\begin{array}{l}\text { Penyusunan } \\
\text { materi; } \\
\text { Penyiapan } \\
\text { media; } \\
\text { Penyusunan } \\
\text { instrument } \\
\text { penilaian; } \\
\text { Seleksi } \\
\text { anggota; } \\
\text { Proses penilaian } \\
\text { hasil; }\end{array}$} \\
\hline $\begin{array}{l}\text { Pengendalian } \\
\text { diri dan } \\
\text { pengelolaan } \\
\text { emosi }\end{array}$ & $\begin{array}{l}\text { Bimbingan } \\
\text { kelompok }\end{array}$ & \\
\hline $\begin{array}{l}\text { Mengatasi } \\
\text { konflik }\end{array}$ & $\begin{array}{l}\text { Konseling resolusi } \\
\text { konflik } \\
\text { (kelompok/ } \\
\text { perorangan); } \\
\text { Mediasi }\end{array}$ & \\
\hline $\begin{array}{l}\text { Menghadapi } \\
\text { perceraian }\end{array}$ & $\begin{array}{l}\text { Konseling kognitif } \\
\text { behavioral }\end{array}$ & \\
\hline
\end{tabular}

\begin{tabular}{|c|c|c|}
\hline Konten & Strategi & $\begin{array}{l}\text { Dukungan } \\
\text { sistem }\end{array}$ \\
\hline $\begin{array}{l}\text { orang tua } \\
\text { /kematian/keh } \\
\text { ilangan } \\
\text { anggota } \\
\text { keluarga/ } \\
\text { orang-orang } \\
\text { dekat }\end{array}$ & $\begin{array}{l}\text { (kelompok/perora } \\
\text { ngan) }\end{array}$ & $\begin{array}{l}\text { Berkolaborasi } \\
\text { dengan guru } \\
\text { dan orang tua } \\
\text { dlm penilaian } \\
\text { hasil layanan; } \\
\text { Perencanaan } \\
\text { tindak lanjut; } \\
\text { dan Penyusunan } \\
\text { laporan }\end{array}$ \\
\hline
\end{tabular}

Tujuan bimbingan klasikal dengan topik kecerdasan manusia adalah: siswa dapat memahami hakikat kecerdasan; memahami kaitan antara kecerdasan dengan pengembangan keterampilan belajar dan pengembangan potensi dalam pencapaian tujuan karir. Melalui penyampaian kurikulum bimbingan siswa-siswa yang membutuhkan layanan responsif akan teridentifikasi, dari hasil penilaian kegiatan baik penilaian proses maupun hasilnya akan diperoleh siswa-siswa mana yang belum memperoleh pemahaman dan atau menunjukkan sikap-sikap tertentu sebagai kompetensi yang diharapkan dalam layanan dasar. Dari lembar refleksi yang siswa tulis beberapa diantaranya menyatakan tentang pikiran apatis mereka bahwa kecerdasan tidak berbanding lurus dengan kesuksesan karier seseorang, mereka mempercayai bahwa faktor keberuntungan lebih dominan dalam menentukan kesuksesan. Sebagai tindak lanjut dari hasil penilaian tersebut konselor merencanakan kegiatan layananan responsif dapat berupa bimbingan / konseling kelompok atau konseling individual, yang bertujuan untuk memberikan siswa pandangan positif mengenai potensi mereka dan rencana pencapaian citacitanya.

Melalui kegiatan perencanaan individual berupa bimbingan penyampaian informasi hasil asesmen psikotes, siswa-siswa yang membutuhkan layanan responsif akan teridentifikasi, dari hasil penilaian kegiatan akan diperoleh siswa-siswa mana yang belum dapat mencapai kompetensi dalam layanan perencanaan individual. kegiatan bimbingan topik: Penetapan tujuan dan penyusunan rencana untuk pengembangan keterampilan belajar bertujuan agar siswa dapat: merumuskan tujuan belajar kedalam tujuan jangka panjang dan jangka pendek; dan menyusun rencana kegiatan-kegiatan untuk mencapai tujuan belajarnya. Dari hasil penilaian diketahui ada siswa yang belum dapat menemukan kegiatan-kegiatan untuk pencapaian prestasinya, siswa tersebut perlu diberi tindak lanjut khusus yang berbeda dari yang lain, wawancara khusus dapat dilakukan agar diperoleh pemahaman lebih mendalam tentang kesulitan siswa, selanjutnya ditawarkan konseling individual.

Kegiatan dalam dukungan system dilakukan antara lain untuk : (1) mempersiapkan pelaksanaan layanan, yaitu penyusunan: rencana layanan, materi, media, teknik dan instrument penilaian; konsultasi, 
koordinasi dan kolaborasi dengan guru mapel, wali kelas, kepala sekolah dan orang tua untuk persiapan layanan; (2) dan penilaian hasil layanan konsultasi, koordinasi dan kolaborasi dengan guru mapel, wali kelas, kepala sekolah dan orang tua untuk proses penilaian; (3) termasuk pelatihan bagi guru BK pemula yang akan bertugas, atau yang belum menguasai terhadap konten-konten atau strategi layanan tertentu yang akan ditugaskan; (4) pelaporan dan rencana tindak lanjut.

\section{TANTANGAN DALAM MEREALISASIKAN PROGRAM BK KOMPREHENSIF}

Dalam merealisasikan program BK komprehensif mungkin akan menghadapi beberapa tantangan, tantangan itu dapat meliputi:

1. Diperlukannya pengetahuan dan keterampilan untuk melakukan beberapa kegiatan dalam komponen program yang sebelumnya belum dimiliki oleh guru BK, contoh: dalam komponen perencanaan individual, untuk membantu setiap siswa dalam merencanakan pengembangan pribadi sosial, belajar dan karier, guru BK perlu memiliki pengetahuan dan keterampilan dalam menginterpretasi dan menginformasikan hasil tes (student Appraisal) kepada siswa, orang tua dan guru, serta pengetahuan dan keterampilan dalam mengajarkan kepada setiap siswa untuk menetapkan tujuan; guru BK dalam program komprehensif dituntut untuk menjadi akuntabel, seluruh layanan yang dilakukan harus dinilai bukan saja prosesnya, akan tetapi hasil dari layanan harus terukur, untuk memberikan bukti bahwa program BK mampu memberi dampak terhadap prestasi siswa, mengingat lemahnya penilaian guru BK terhadap layanan selama ini, maka diperlukan pengetahuan dan keterampilan dalam penilaian terhadap hasil layanan.

2. Sikap resisten dari beberapa pihak terhadap program, pihak lain diluar personel BK mungkin belum dapat menerima perubahan, yang mereka tahu bahwa tugas guru BK adalah pekerjaan-pekerjaan yang selama ini dilakukan, seperti petugas piket yang memberikan ijin siswa untuk meninggalkan sekolah atau masuk kelas, penerima surat, petugas absensi, pemberi sanksi pada siswa yang terlambat, penerima tamu dll. Tentunya pekerjaan-pekerjaan itu harus ada yang menggantikan, bila dalam program telah dideskripsikan secara rinci tugas-tugas konselor yang dilengkapi dengan jadwal kegiatan semesteran, bulanan, mingguan dan harian, maka kepala sekolah akan mengambil kebijakan untuk menugaskan personel lain yang lebih sesuai dengan tugas-tugas tersebut.

3. Dari pihak konselor sendiri banyak yang memiliki sikap enggan untuk melakukan perubahan, karena dalam merealisasikan program BK tenaga dan waktu yang harus digunakan akan lebih banyak, dalam hal ini koordinator BK harus mampu mendorong para staf untuk memiliki kesadaran akan tanggungjawab terhadap tugas pokok BK, selain itu koordinator harus dapat memfasilitasi peningkatan kompetensi staf dalam implementasi program.

Gysbers (2011) memberikan saran-saran dalam upaya mengimplementasikan program BK komprehensi secara utuh, terdapat beberapa langkah yang harus dilakukan, yaitu:

1. Pertama yang paling penting dilakukan adalah merencanakan pengalihan kegiatan-kegiatan diluar tugas-tugas bimbingan dan konseling kepada pihak lain yang lebih sesuai, sehingga konselor dapat mengembangkan kalender kegiatan sendiri sesuai dengan ketersediaan waktu untuk melaksanakan keempat komponen program;

2. Meminta persetujuan dari para pemangku kebijakan pendidikan di daerah, pihak tersebut harus mengetahui tentang program sehingga mereka dapat merencanakan pemberian dukungan;

3. Terakhir adalah penting dilakukannya upayaupaya penginformasian untuk menyampaikan kepada para personel sekolah, para orang tua/wali murid dan masyarakat tentang kemanfaatan dari program BK komprehensif.

\section{PENUTUP}

\section{Simpulan}

Permendikbud No 111 tahun 2014 telah memberikan ketetapan untuk reorganisasi program bimbingan dan konseling. Bagian penting yang berbeda dari program selama ini yaitu empat komponen program yang harus diimplementasikan, yang satu sama lain tidak dapat terpisahkan. Pengorganisasian program dengan empat komponen tersebut dapat memberikan ruang lebih luas dalam bekerja bukan saja untuk menangani siswa bermasalah, akan tetapi juga untuk upaya pencegahan dan pengembangan.

Selain berimplikasi terhadap tugas-tugas dan kompetensi tertentu dalam pelaksanaan program, Program BK komprehensif juga mengamanatkan dipenuhinya tuntutan akuntabilitas dalam program yang dilakukan guru BK, karena konselor/guru BK merupakan pendidik seperti umumnya guru yang melakukan penilaian terhadap hasil pembelajaran. Guru BK harus dapat membuktikan bahwa program bimbingan dan konseling memberikan dampak terhadap prestasi peserta didik.

\section{Saran}

1. Operasionalisasi program BK komprehensif secara utuh di sekolah bukanlah pekerjaan sederhana, diperlukan tenaga, waktu, sarana prasarana yang memadai. Untuk itu amat penting diperolehnya dukungan dari kepala sekolah dan seluruh personel di sekolah, orang tua serta pihak-pihak di masyarakat. 
2. Faktor penting yang berpengaruh terhadap operasionalisasi Permen Dikbud No 111 Tahun 2014 adalah pengawasan, walaupun telah dilakukan sosialisasi dan pelatihan kepada guru BK tetapi bila tidak ada tindak lanjut monitoring ke sekolah maka tidak akan terealisasi dengan baik.

3. Kepala sekolah dan pengawas perlu diberi kesempatan ikut dalam sosialisasi panduan, serta pelatihan dalam supervisi pelaksanaan program BK komprehensif.

\section{DAFTAR PUSTAKA}

Asosiasi Bimbingan dan Konseling Indonesia. 2006. Rambu-Rambu Penyelenggaraan Bimbingan dan Konseling dalam Jalur Pendidikan Formal (Naskah Akademik). Bandung: Depdiknas.

American School Counselor Association. 2005. The ASCA National Model: A Framework For School Counseling Programs (2 $2^{\text {nd }}$ Edition). Alexandria, VA: Author.

American School Counselor Association. 2009. The role of the professional school counselor. Retrieved from http://www.schoolcounselor.org/content.asp?contenti $\mathrm{d}=240$.

Badrujaman, A. et al. 2013. Kontribusi Layanan Dasar terhadap Pencapaian Hasil Belajar Siswa: Studi evaluasi terhadap dampak layanan dasar. Disampaikan dalam kongres XII ABKIN.

Connecticut School Counselor Association. 2001. Best Practices for School Counseling in Connecticut: Counselor Competencies, Model Job Description and Evaluation Guidelines.

Erford, B.T. 2015. Transforming The School Counseling Profession. Fourth Edition. Person Education.

Florida Department of Education. 2010. Florida's School Counseling Framework. State of Florida Department of State.

Gysbers, N.C, \& Henderson, P. 2006. Developing and managing your school guidance and counseling program. Alexandria, VA: American Counseling Association.

Gysbers, N. C., \& Henderson, P. 2001. Professional School Counseling: Comprehensive Guidance and Counseling Programs: A Rich History and a Bright Future. 4(4), 246.

Gysber,N.C. 2011. Missouri Comprehensive Guidance and Counseling Program: A Manual for Program Development, Implementation, Evaluation and Enhancement. Missouri Center for Career ducation
University of Central Missouri Warrensburg: Missouri.

Gysbers, N.C. 1983. Create and Use Career Individual Plan. Columbia. The National Center for Research in Vocational Education. The Ohio State University.

Kemendikbud. 2014. Permendiknas No 111: Bimbingan dan Konseling pada Pendidikan Dasar dan Pendidikan Menengah.

State of Arizona Department of Education. 2007. The Arizona Model:A Framework for School Counseling Programs. Office of John Huppenthal Superintendent of Public Instruction.

Johnson, Y.D \& Ninnall, S.E. 2009. Comprehensive School Counseling Program Guide. Springfield Public Schools New York Institute of Technology

South Carolina Department of Education. 2008. South Carolina Comprehensive School Counseling Program Guide. Columbia

Texas Education Agency. 2004. A Model Comprehensive, Developmental Guidance and Counseling Program

Utah State Office of Education. 2008. Utah Model for Comprehensive Counseling and Guidance: $K-12$ Programs. Salt Lake City: Utah State Office of Education.

Washington State Office of Superintendent of Public Instruction. 2007. Washington's Navigation 101 program. http://Washington's.navigation $101 . c o m$ 